\title{
Driving Factors of Globalization: An Em pirical Analysis of the Developed and Developing Countries
}

\author{
Ayesha Naz ${ }^{1}$, Eatzaz Ahmad ${ }^{2}$
}

\begin{abstract}
There are several economic, political, social and technological factors that have contributed to globalization in recent decades. The literature has yet to come up with a comprehensive analytical framework. Present study develops a formal framework, which highlights the sources of globalization. Furthermore, the study also provides an empirical test for driving factors of globalization in developed and developing countries. Results of dynamic ordinary least square show human capital, capital, labor, transportation and communication and financial index as the important drivers of globalization in both developed countries and full sample. However, capital, labor and financial index appear to determine the process of globalization in developing countries. For robustness of the results, Generalized Method of Moments (GMM) is also applied; the results in full panel and developing countries are similar. However, efficiency index appears to be significant. In the panel of developed countries human capital, transportation and communication and financial index are significant.
\end{abstract}

Key words: Globalization, human capital, efficiency index, financial index, GMM

\section{Introduction}

Economies around the world are becoming strongly integrated. The process of this integration is not new, as historical data suggests that the very first wave of globalization in the modern era occurred in 1870 (Mishkin, 2006). However, the interdependence and interconnectivity has been increasing over the past few decades. Multi-dimensional integration among countries around the world is a result of globalization in which socio-cultural, political and economic relations are established across a geographic distance. World has witnessed increase in the flows of trade, investment, capital and information during the process of integration. Mobility of individuals across the globe has also increased. Globalization not only increases economic and financial interdependencies among countries but it also integrates the social and political aspects.

1 Assistant Professor, International Islamic University, Islamabad. Email: ayeshanaz44@yahoo.com

2 Professor, University of Peshawar, Peshawar.

\begin{tabular}{lll} 
ARTICLE HISTORY & & \\
$19 \mathrm{Dec}, 2017$ Submission Received & 19 Jan, 2018 & First Review \\
\hline 20 Feb, 2018 Revised Version Received & 12 Mar, 2018 & Second Review \\
\hline $15 \mathrm{Mar}, 2018$ Revised Version Received & 20 Mar, 2018 & Accepted
\end{tabular}


The current shape and pace of globalization is driven by several factors. Broadly speaking, economic, financial, political, technological and social factors have paved the way to globalization. Economic factors mainly include lower trade and investment barriers. Expansion of financial sector is also considered an important force of globalization. Integration and unification of financial markets around the globe through financial liberalization and deregulation has increased the mutual dependencies of the economies. According to Stiglitz and Greenwald (2003), capital account liberalization is elimination of rigid rule and regulations in developing countries that could advance the flow of money.

Political factors can be defined in term of government policies that are designed to facilitate trade and commerce in view of globalization. Moreover, these polices are instrumental in channelizing the flow of finance and capital. The process of globalization is led by a number of national and international institutes and countries in formulating policies. Earlier surge of globalization seems to be highly concentrated among developed nations (Maddison, 2001). However, the contribution of emerging market economies in international trade has been increasing significantly in past few years.

Technology plays an important role in expediting the process of globalization. It is conceived as a major facilitator and a driving force in the globalization processes. Technological improvement has allowed companies to rapidly globalize their products. Multinational food chains are able to reproduce and standardized their products across globe through fine connectivity coordinated by technology. The development of containerized ships and air freight is considered to be a key technological advancement in trade and commerce. Similarly, the introduction of universal bar code has increased the movement and flow of goods worldwide. The creation of personal computers and internet created electronic business (E-Business) and electronic commerce (E-Commerce), which are used as a justification of recent techno-globalism. Financial sector is also benefitted from technology through electronic banking. Electronic transfer of funds is considered to be the first operating form of global electronic financial system. The modern era of globalization is now experiencing 'internet economies' due to advancement in technology. Internet growth is a key factor for developing interpersonal relationship across the globe. It is one of the necessary components for social globalization, and without the invention of internet it would be incomplete.

Social factors bring cultural convergence, that is, increasing similarity throughout the world, through significant reduction in transport and communication cost. Nowa-days the cost of transmitting information is almost negligible, shrinking the world to one single market. Individuals and societies are taking advantage of this enormous reduction in cost by using standard brands and services worldwide. As a result, societies 
are moving towards convergence of taste, which is increasing homogeneity across globe.

The above-mentioned factors have contributed to shaping globalization. These factors are responsible for flattening the world. It is essential to know the potential sources of globalization because the contribution of these factors is not uniform across globe. The extent and intensity of globalization is found to be different among countries and regions. This indicates that the factors which drive the process of globalization may affect differently across developed and developing economies owing to the structural condition of one's country. However, there is a lack of empirical evidence in this regard. Hence, the current study has attempted to address this issue.

The aim of current study is to examine the driving factors of globalization. Growing literature on the causes of globalization reveals several factors that have contributed to the process of globalization. Therefore, in the era of globalization, where it is considered to be irresistible for almost all the developing and developed nations, there is a need to develop some systematic link to its drivers. Hence, this study develops the theoretical and analytical framework that creates a connection of globalization to its driving forces. Furthermore, the empirical investigation of the contribution of each factor of globalization in developed and developing countries will enlighten the role of significant factors.

This study has several contributions to the existing literature of globalization. First, the study develops an analytical framework for the driving factors of globalization. All the available studies only describe the driving factors of globalization. Second, it provides an empirical test for the large panel of 92 countries. Third, the empirical analysis is carried out separately for the developed and developing countries. Lastly, this study develops several new indices which are used in the empirical investigation. For instance, efficiency index, macroeconomic instability index and transportation and communication indices are constructed by adding new variables and applying the statistical technique of principal components analysis (PCA). Moreover, these indices are also checked for the goodness of fit.

\subsection{Objectives of the study}

The targeted milestones of the study are as follows,

1. To establish an analytical framework that creates a link of globalization to its driving factors.

2. To provide the empirical test for the causes of globalization.

3. To examine the effect of driving factors in developed and developing countries. 


\section{Driving Factors of Globalization Noted in Literature}

There are many factors that are expected to have contributed in the process of globalization. In this section we will describe all the factors, their importance and relevance in driving globalization.

Advancement in technology is considered to be one of the major divers of globalization (Bang \& Markeset, 2011; Bauernfeind, 2006; Garrett, 2000; Harris, 1993; Masson, 2001; Mussa, 2000; Obadan, 2008). Technological improvement in the area of transportation and communication has accelerated globalization in recent years. The new era of shipping was begun with the creation of the world's first container ship in 1956 (Ritzer, 2011). Containerization has significantly reduced the transportation cost, which in turn has increased the pace of globalization. Introduction of commercial jet aircraft in the 1970s was the great progress that accelerated the transportation of goods among different regions of the globe. Another major technological development in the 1970s was the advancement in microprocessors and telecommunication and then later on the growth of internet (Ritzer, 2011). The main purpose of internet is access to information, business, entertainment and awareness. This source of globalization provides the easy access to everything on a single click. These are few examples of technological improvement. Numerous other technological innovations have affected the process of globalization.

Although reduction in the cost of transportation and communication is associated with technological advancement but only few studies explicitly considered lower cost as a determinant of globalization (Bang \& Markeset, 2011; Bauernfeind, 2006; Ritzer, 2011; World Bank, 2002). Moreover, cost driver shows the variation in cost and efficiency across countries that push national firms to become global (Bauernfeind, 2006).

Another major cause of globalization which is attached to lower transportation and communication cost is the taste of individuals and societies (Mussa, 2000; Obadan, 2008). According to Krugman (1980), individuals have same taste in different countries whereas wide variety of products leads to mutual trade. Taste diversity develop basis for international trade under increasing returns to scale. Economic integration which depends on taste diversification has become possible through cheaper means of transportation.

Lower transport and communication cost can only be exploited through lower trade barriers. Policies aimed at reduction in trade barriers lead to trade liberalization. In addition, deregulation and outward looking reforms are considered to be an important source of globalization. In this context several studies, e.g., Bang and Markeset (2011), Bauernfeind (2006), Fofack (2009), Garrett (2000), Harris (1993), Masson (2001), Mussa (2000), Obadan (2008), Ritzer (2011) and World Bank (2002) 
pointed out government policies as a driving factor of globalization.

Policies directed to financial sector liberalization increase not only capital mobility but also financial integration among different countries. Financial globalization is attributed to capital account liberalization, financial deregulation and financial innovations. Financial globalization creates the mutual borrowing relationship among countries. It can be seen clearly that even the smallest item available in the market has price tags in two types of currency; one local and other is in dollar. Advancements in financial sector increase capital flows around the globe, which is a significant factor of globalization (Lane \& Ferretti, 2008; Fofack , 2009; World Bank, 2002).

The process of industrialization in LDCs is also an important source of globalization. According to Harris (1993), significant output growth in Asian countries between the years 1965 to 1988 has not only increased the share of world GDP, but also increased the global capacity of production. Hence, the output growth of LDCs can be taken as a cause of globalization.

Market and competitive drivers are some other related factors of globalization. Markets provide opportunity to national economy to become global economy through common customer need and optimum utilization of resources with the help of global channels. Interdependencies of countries through trade and FDI and the existence of global competition support competitive drivers.

\section{Theoretical Framework}

It is important to highlight the qualitative contribution of some influential theories of globalization. These theories describe the evolution and emergence of global systems, networks and culture. The contribution of Wallerstein (1974) is thought to be a landmark to devise a theory of world-system. In this system, intellectual participation requires the understanding of whole system. Hence, knowledge creation unveils the structures and provides opportunity for its transformation. World-system is closely related to dependence theory, which is described through core-periphery relationship. It refers to power hierarchy in the world-system, where developed 'core' societies exploit the 'peripheral' societies. Therefore, it is also termed as unequal exchange with organized transfer of surplus from periphery to core. The division of core and periphery societies is critically dependent on technology. The system is a global class struggle; tension between the efforts of domination and resistance to this domination. Therefore, the world system is the economic and political interdependent of core-periphery societies, which is positioned by technology.

The idea of wired or network society is related to the role of information and communication in the society. It emphasizes on the social implications of globaliza- 
tion. Martin (1978), Dijk (1991) and Castells (1996) defined network society, where social, cultural, economic and political relations of the societies are diversified by the spread of microelectronic based information and communication technology. These relations are less bounded by time and spatial location. Media and social networks link individuals, organization and society at all levels. Therefore, the network society is termed as 'glocal' as its scale is global and local. The outcome of network society is seen in production, power, culture and experience. The network society allows the process of globalization through the channel of modern information and communication technology.

The theory of global capitalism is another important contribution to describe the phenomenon of transnational world. In this theory, Robinson (2004) characterized the current period in the fourth stage of capitalism; the age of information and technology. The new era of capitalism is different from other social systems due to commodification and marketization of social relationships. It deepens the capital impact on all the structures. This theory points out the rise of transnational capital as a source of economic globalization. It allows the national units of production process to transform into global units. Hence, trans-nationalization of production and capital ownership derives the process of globalization.

Harvey (1990) argued that globalization shows 'time-space compression' which is created by development of capitalism. Similarly, Giddens (1990) described the crux of globalization as time-space distanciation. In the theories of time and space, social relations are lifted from local to global scale and restructured across space and time. Sassen (1991) theory of global cities proposed dynamic spatial order of global cities. In this theory, major cities (New York, London and Tokyo) redefine their spatial and social relations to access peripheralzed labor markets. The idea of global cities is taken up by the theories of trans-nationality and transnationalism but on larger scale. Transnationalism defines multiple transformations (economic, political, social and cultural) and interactions (individuals, communities and institutions) at local and global level. Transnational migration theorist highlights the intense relations among individuals and groups due to inexpensive and speedy modes of communication.

Classical theories of globalization mostly show technology as an important driver of globalization while some other theories highlight the role capital in determining the process of globalization.

\section{Analytical Framework and Methodology}

We have selected three factors of globalization which are output, technology and financial sector development in line with available literature and theoretical frame- 
work. These three factors are comprehensive in nature. However, several other factors that are highlighted by the literature are also considered as driving forces since the functions of these three variables directly or indirectly link other factors to globalization. Furthermore, these factors cover all the four major aspects of globalization i.e. economic, financial, political, social and technological.

In the light of above discussion we can start with a functional relationship of globalization with its three main drivers. Since this basic relationship is to be linked up further to a number of socioeconomic and political variables, we make the matter simple by assuming the simple Cobb-Douglas form that considers the three drivers of globalization as imperfect substitutes. Thus, for example, a country can become more globalized by establishing better economic or political links with rest of the world but it cannot gain globalization just by considering one aspect and ignoring others. This functional form also implies that the three drivers complement each other in the sense that marginal return to any one driver is positively related to the levels of other drivers. This functional relationship is given by:

$$
G_{t}=C Y_{t}^{\left(\alpha_{1}\right)} T_{t}^{\left(\alpha_{2}\right)} F_{t}^{\left(\alpha_{3}\right)},
$$

where $G_{t}, Y_{t}, T_{t}$ and $F_{t}$ represent globalization, output, technology and financial sector development respectively and $\mathrm{C}$ is a constant that captures the causes of globalization, which are not explained by output, technology and financial sector development. The globalization variable is an index constructed on the basis of a number of indicators of globalization. ${ }^{3}$

Growth of output depends upon production function, which is here specified in cobb Douglas form:

$$
Y_{t}=A_{t} B_{t}^{\theta} K_{t}^{\alpha} L_{t}^{\beta}
$$

$A_{t}$ is the general level of technology/knowledge at period $t$. is the variable of efficiency and $k_{t}$ and $L_{t}$ are the amounts of capital and labor respectively devoted to produce output in period t. The parameters $\theta, \alpha$, and $\beta$ are the production elasticities of efficiency, capital and labor respectively.

The stock of knowledge, $A_{t}$, is the accumulation of ideas that have been discovered by researchers. Theoretically, the idea of knowledge creation for the development of world-system is presented by Wallerstein (1974). However, formally the phenomenon of knowledge creation is described in research and development $(R \& D)$ based growth models (Romer, 1990; Grossman \& Helpman, 1991a, 1991b, 1991c; Aghion \& Howitt, 1990; Jones, 1995). According to these models, creation of new knowledge

3 See section 5 for detail. 
is determined by the amount of researchers engaged in $R \& D$ and the existing stock of knowledge available to researchers. $A_{t}$ is the existing stock of knowledge available at time period $t$ while $\Delta \mathrm{A}_{\mathrm{t}}$ is the flow of new knowledge and ideas.

Following the traditional framework of $R \& D$ growth models, flow of knowledge can be described as follows,

$$
\Delta A_{t}=\bar{\delta} R_{t-1}
$$

where $\bar{\delta}$ is the average research productivity i.e. number of new ideas created per researcher and $R_{t-1}$ is the number of researchers. The average research productivity depends on the existing stock of knowledge, $A_{t-1}$ and the number of researchers, $R_{t-1}$. It is defined as follows;

$$
\bar{\delta}=\delta A_{t-1}^{\phi} R_{t-1}^{\lambda-1}
$$

where $\delta, \phi$, and $\lambda$ are parameters. $A^{\phi}$ shows the dependence of current research productivity on past discoveries and ideas. Past discoveries and inventions are helpful for the creation of new knowledge. Current research productivity can be increased or decreased in the stock of knowledge, depending upon the sign of $\phi$. If $\phi>0$, then current research productivity is increasing in the stock of knowledge, known as 'spillover of knowledge'. The idea of spillover of knowledge was first developed by Alfered Marshall in 1890 and then later on it was extended by Arrow (1962) and Romer (1986). In case, if $\phi<0$, then the current research productivity is decreasing in the stock of knowledge that has already been discovered. It is termed as 'fishing out effect', which state that it is more difficult for the researchers to find new ideas and dimensions because the obvious ideas have already been discovered. Current research productivity will become independent of the stock of knowledge in case where $\phi=0$.

$\mathrm{R}^{\lambda-1}$ shows that research productivity depends on the numbers of researchers. If large numbers of researchers are searching for new ideas, then there is possibility of replication and overlap of research. It will decrease the total number of ideas by the researchers at a point in time. In that case research productivity is decreasing in so, $0<\lambda<1$.

Substituting equation 4.4 in equation 4.3 yields:

$$
\Delta A_{t}=\delta A_{t-1}^{\phi} R_{t-1}^{\lambda}
$$

Equation 4.5 presents the flow of ideas or knowledge. In order to get the stock of knowledge at time period $\mathrm{t}$, the equation will be as follows,

$\frac{A_{t}}{A_{t-1}}=\delta A_{t-1}^{\phi} R_{t-1}^{\lambda}$ 


$$
A_{t}=\delta A_{t-1}^{\phi+1} R_{t-1}^{\lambda}
$$

Equation 4.7 shows that the current stock of knowledge depends on past ideas and the number of researchers engaged in creating new ideas with the help of already discovered ideas.

The variable of efficiency ' $\mathrm{B}$ ' depends on the performance and policies of the government. It can be measured by using indicators on trade openness and macroeconomic conditions. Following Kneller and Steven (2002) and Fofack (2009), the efficiency factor can represented as a composite index based on a number of factors, namely economic diversification, index of reallocation of labor across sectors, degree of competitiveness, macroeconomic instability and governance index.

We get equation 4.8 by substituting equation 4.7 in 4.2

$$
Y_{t}=\left(\delta A_{t-1}^{\phi+1} R_{t-1}^{\lambda}\right) B_{t}^{\theta} K_{t}^{\alpha} L_{t}^{\beta}
$$

Substituting 4.8 in 4.1, yields

$$
G_{t}=C\left[\left(\delta A_{t-1}^{\phi+1} R_{t-1}^{\lambda}\right) B_{t}^{\theta} K_{t}^{\alpha} L_{t}^{\beta}\right]^{\alpha_{1}} T_{t}^{\alpha_{2}} F_{t}^{\alpha_{3}}
$$

It is already discussed that improvement in the technology of communication and transportation played a critical role in globalization. Therefore, we define technology as follows,

$$
T_{t}=F\left(T_{c t}, T_{p t}\right)
$$

Where $\mathrm{T}_{\mathrm{ct}}$ and $\mathrm{T}_{\mathrm{pt}}$ are communication and transportation technology respectively.

We reconsider equation 4.7 to find the value of $\mathrm{A}_{\mathrm{t}}$

$$
A_{t}=\delta A_{t-1}^{\phi+1} R_{t-1}^{\lambda}
$$

Consider, $\phi+1=\gamma$

$$
A_{t}=\left(\delta A_{t-1}^{\gamma} R_{t-1}^{\lambda}\right)
$$

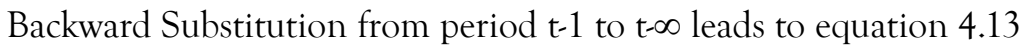

$$
A_{t}=\delta^{\left[1+\gamma+\gamma^{2}+\gamma^{3} \cdots \cdots .\right]} R_{t-1}^{\lambda} R_{t-2}^{\gamma \lambda} R_{t-3}^{\gamma^{2} \lambda} \cdots \cdots \cdots
$$

Assuming $|\gamma|<1$ and applying standard formula for the sum of geometric series in the power of $\delta$, yields:

$$
A_{t}=\delta^{\frac{1}{1-\gamma}} R_{t-1}^{\lambda} R_{t-2}^{\gamma \lambda} R_{t-3}^{\gamma^{2} \lambda} \ldots \ldots \ldots
$$


Substituting equation 4.14 in 4.9 , and assume $c=1$

$G_{t}=\left[\left(\delta^{\frac{1}{1-\gamma}} R_{t-1}^{\lambda} R_{t-2}^{\gamma \lambda} R_{t-3}^{\gamma^{2} \lambda} \ldots \ldots . . .\right) B_{t}^{\theta} K_{t}^{\alpha} L_{t}^{\beta}\right]^{\alpha_{1}} T_{t}^{\alpha_{2}} F_{t}^{\alpha_{3}}$

Taking one period lag and power of equation 4.15 yields equation 4.16 :

$G_{t-1}^{\gamma}=\left[\left\{\left(\delta^{\frac{1}{1-\gamma}} R_{t-1}^{\lambda} R_{t-2}^{\gamma \lambda} R_{t-3}^{\gamma^{2} \lambda} \ldots \ldots . . .\right) B_{t}^{\theta} K_{t}^{\alpha} L_{t}^{\beta}\right\}^{\alpha_{1}} T_{t}^{\alpha_{2}} F_{t}^{\alpha_{3}}\right]^{\gamma}$

Dividing two sides of equation 4.15 by the corresponding sides of 4.16 , results in the following equation.

$$
G_{t}=\delta^{\alpha_{1}} R_{t-1}^{\alpha_{1} \lambda} B_{t}^{\alpha_{1} \theta} K_{t}^{\alpha_{1} \alpha} L_{t}^{\alpha_{1} \beta} T_{t}^{\alpha_{2}} F_{t}^{\alpha_{3}} B_{t-1}^{-\alpha_{1} \theta \gamma} K_{t-1}^{-\alpha_{1} \alpha \gamma} L_{t-1}^{-\alpha_{1} \beta \gamma} T_{t-1}^{-\alpha_{2} \gamma} F_{t-1}^{-\alpha_{3} \gamma} G_{t-1}^{\gamma}
$$

Or, applying logarithm on both sides:

$$
\begin{aligned}
& \log G_{t}=\alpha_{1} \log \delta+\alpha_{1} \lambda \log R_{t-1}+\alpha_{1} \theta \log B_{t}+\alpha_{1} \alpha \log K_{t}+\alpha_{1} \beta \log L_{t}+\alpha_{2} \log T_{t}+ \\
& \alpha_{3} \log F_{t}-\alpha_{1} \theta \gamma \log B_{t-1}-\alpha_{1} \alpha \gamma \log K_{t-1}-\alpha_{1} \beta \gamma \log L_{t-1}-\alpha_{2} \gamma \log T_{t-1}- \\
& \alpha_{3} \gamma \log F_{t-1}+\gamma \log G_{t-1}
\end{aligned}
$$

Equation 4.18 can be expressed in linear form as the objective of this study is to highlight the drivers of globalization and the contribution of each factor in its advancement. For this purpose, we drive equation 4.19 by transforming all the coefficients to $\beta$ 's as given below;

$$
\begin{aligned}
& \beta_{0}=\alpha_{1} \log \delta, \beta_{1}=\alpha_{1} \lambda, \beta_{2}=\alpha_{1} \theta, \beta_{3}=\alpha_{1} \alpha, \beta_{4=} \alpha_{1} \beta, \beta_{5}=\alpha_{2}, \\
& \beta_{6}=\alpha_{3}, \beta_{7}=\alpha_{1} \theta \gamma, \beta_{8}=\alpha_{1} \alpha \gamma, \beta_{9}=\alpha_{1} \beta \gamma, \beta_{10}=\alpha_{2} \gamma, \beta_{11}=\alpha_{3} \gamma \text { and } \beta_{12}=\gamma \\
& \log G_{t}=\beta_{0}+\beta_{1} \log R_{t-1}+\beta_{2} \log B_{t}+\beta_{3} \log K_{t}+\beta_{4} \log L_{t}+\beta_{5} \log T_{t}+\beta_{6} \log F_{t}- \\
& \beta_{7} \log B_{t-1}-\beta_{8} \log K_{t-1}-\beta_{9} \log L_{t-1}-\beta_{10} \log T_{t-1}-\beta_{11} \log F_{t-1}+\beta_{12} \log G_{t-1}
\end{aligned}
$$

Equation 4.19 presents globalization index $\mathrm{G}_{\mathrm{t}}$, researchers $\mathrm{R}_{\mathrm{t}-1}$, efficiency index $\mathrm{B}_{\mathrm{t}}$, capital stock $\mathrm{K}_{\mathrm{t}}$, labor force $\mathrm{L}_{\mathrm{t}}$, transportation $\&$ communication technology $\mathrm{T}^{\mathrm{t}}$ and financial development $\mathrm{F}_{\mathrm{t}}$ as the main factors of globalization.

For panel data analysis equation 4.19 can be expressed as follows,

$$
\begin{aligned}
& \log G_{i t}=\beta_{0}+\beta_{1} \log R_{i t-1}+\beta_{2} \log B_{i t}+\beta_{3} \log K_{i t}+\beta_{4} \log L_{i t}+\beta_{5} \log T_{i t}+ \\
& \beta_{6} \log F_{i t}-\beta_{7} \log B_{i t-1}-\beta_{8} \log K_{i t-1}-\beta_{9} \log L_{i t-1}-\beta_{10} \log T_{i t-1}-\beta_{11} \log F_{i t-1}+ \\
& \beta_{12} \log G_{i t-1}
\end{aligned}
$$

Equation 4.20 is the panel dynamic version that links globalization to its drivers.

\section{Data and Variables}

The present study uses balanced panel data of 92 developed and developing countries over the period of 1995 to $2015^{4}$. Limited availability of data, particularly

4 See appendix-I for list of countries 
on the variables of transportation in developing countries, restricted the sample size. Annual data of selected variables are collected from various sources. Detail of each variable used in the empirical model (equation 4.20) is provided below.

\subsection{Globalization index $\left(\mathrm{G}_{\mathrm{it}}\right)$}

Globalization index is a composite index consisting of three main categories of globalization namely economic, political and social globalization. It is a comprehensive index and is constructed with the help of 23 variables. Economic globalization includes trade, FDI, portfolio investment and income to foreign nationals, while import barriers, tariff, taxes on trade and capital account restrictions are also taken into consideration. Political globalization is considered as a diffusion of government policies and measured by number of embassies, membership in international organizations, participation in UN peace keeping missions and international treaties signed between two or more states. Social globalization is characterized by spread of information, ideas and people. Data on this index are collected from ETH Zurich database.

\subsection{Human capital index (Proxy for researchers, $R_{i t-1}$ )}

This index is used in place of researchers because the data on number of researchers are available only for a limited number of countries, especially developing countries. The current study uses human capital index that is based on years of schooling and returns to education and is taken from Penn World Table.

\subsection{Efficiency index $\left(\mathrm{B}_{\mathrm{it}}\right)$}

Efficiency index is constructed following the procedure given in Kneller and Steven (2002) and Fofack (2009). It has five components; economic diversification (d), reallocation of labor across sectors (a), international competiveness (c), macroeconomic instability $(\mu)$ and governance index $(\mathrm{g})$. Each indicator is normalized to eliminate scale biasness and then weights are assigned by applying the technique of PCA. Goodness of fit of this index is measured by discrepancy, root mean square residual (RMSR) and Bentler-Bonnet normed fit index (NFI). Smaller values of discrepancy and RMSR are desirable while NFI should be 0.90 or greater. Therefore, the value of discrepancy, RMSR and NFI are $0.0196,0.0443$ and 0.9478 respectively, which are adequate for fit index. The efficiency index is constructed as follows,

$$
B=w_{1} d+w_{2} a+w_{3} c+w_{4} \mu+w_{5} g
$$

Where $\mathrm{w}_{\mathrm{i}}$ is the weight assigned to component $\mathrm{i}$. The details on each of the five components of the index are given below. 


\subsubsection{Economic diversification (d)}

Economic diversification is a process of growing range of produced output. It is also referred as a market diversification for exports or economic activities. Data on this index are collected from UNCTAD. It ranges from zero to one. The index shows greater divergence from world pattern, if the value is closer to one.

\subsubsection{Reallocation of labor across sectors index (a)}

This index shows the adjustment of labor from traditional to the modern developed sectors as a consequence of structural change of the economies. This index is constructed by considering three sector namely, agriculture, industry and services. Employment changes for each sector are calculated and then the values of these three sectors are added to obtain the index of reallocation of labors across sector. Finally, we normalize the index by following the traditional way. The construction of index is given below,

$$
\begin{aligned}
& X=\left|\Delta L_{a}\right|+\left|\Delta L_{i}\right|+\left|\Delta L_{s}\right| \\
& \text { Reallocation IndeX }=\frac{X-X_{\text {min }}}{X_{\text {max }}-X_{\text {min }}}
\end{aligned}
$$

where $\Delta L_{a}, \Delta L_{i}, \Delta L_{s}$ show employment change in agriculture, industry and services sector respectively. Data on employment in agriculture, industry and services as a percentage of total employment are collected from World Bank database.

\subsubsection{International competitiveness (c)}

In this study degree of international competiveness is measured by real effective exchange rate (REER). It is the weighted average of local currency against the index of major foreign currencies, adjusted for inflation. Data are extracted from Bruegel datasets and World Bank database with year 2010 as a base year.

\subsubsection{Macroeconomic instability $(\mu)$}

Extending the methodology of Ali and Rehman (2015), present study uses five indicators for the construction of macroeconomic instability index. It includes inflation rate, budget deficit, current account deficit, unemployment and external debt. Data on all these variables are collected from World Bank database. Each variable is normalized before the construction of composite index. After normalization, weights are derived through PCA. Some diagnostic tests are also performed on the index. It shows that Discrepancy (0.0180), RMSR (0.0425) and NFI (0.9109) are in the fit index range. 


\subsubsection{Governance index (g)}

Governance index is measured with the help of six dimensions that are mentioned in worldwide governance indicators. These dimensions are as follows; control of corruption, government effectiveness, political stability and absence of violence or terrorism, regulatory quality, rule of law and voice $\&$ accountability. Each indicator is normalized and weighted equally to construct governance index. The index is ranges from zero to one. Values closer to one indicate good governance.

\subsection{Capital stock $\left(\mathrm{K}_{\mathrm{it}}\right)$}

Data on capital stock is generated by using a standard perpetual inventory model of the following form,

$$
K_{t}=(1-\delta) k_{t-1}+I_{t-1}
$$

The capital stock at period $t, \mathrm{~K}_{\mathrm{t}}$, can be expressed as a function of capital stock at period $\mathrm{t}-1, \mathrm{k}_{\mathrm{t}-1}$, gross investment in the preceding period, $\mathrm{l}_{\mathrm{t}-1}$, and depreciation, $\delta$, of $\mathrm{k}_{\mathrm{t}-1}$,

Solving equation 5.1 for the stock of capital in period t -1 yields equation 5.2,

$$
\begin{aligned}
& K_{t}-k_{t-1}+\delta k_{t-1}=I_{t-1} \\
& {\left[\frac{K_{t}-k_{t-1}}{k_{t-1}}+\delta\right] k_{t-1}=I_{t-1}} \\
& {\left[g_{k}+\delta\right] k_{t-1}=I_{t-1}} \\
& k_{t-1}=\frac{I_{t-1}}{g_{k}+\delta}
\end{aligned}
$$

The above equation is similar to the one solved by Harberger (1978) under the framework of neoclassical growth theory. Where $g_{k}$ is the compound GDP growth rate over the entire period, calculated separately for each country, while the rate of depreciation is taken 5 percent as suggested by Reynolds (1971) and Looney (1985). Data on capital formation are obtained from World Bank database.

\subsection{Labor force $\left(\mathrm{L}_{\mathrm{it}}\right)$}

Data on labor force are extracted from World Bank database.

\subsection{Transportation and communication index $\left(\mathrm{T}_{\mathrm{it}}\right)$}

This index has two dimensions, i.e. transportation and communication. The index is constructed by assigning equal weights to these dimensions as both are equally 
important. These two dimensions are explained below,

\subsubsection{Transportation index}

Three main categories of transportation i.e. air, railway and marine are considered to drive composite index. To determine air connectivity, we have used air freight (million ton- $\mathrm{km}$ ), passengers carried and registered carrier departures worldwide. These three variables are selected to show domestic and worldwide movement of goods and passengers. In the railway category, goods transported (million ton-km) and passengers carried (million passenger-km) have been chosen to indicate the domestic and neighboring region connectivity via railway tracks.

Now-a-days, extensive roads networks are replacing the railway network because of its low maintenance cost. However, limited data availability restricts this indicator to become a part of transportation index. Data on air and railway transport are collected from World Bank database and CIA World Fact Book. Whereas, merchant marine (fleet) data, measured in deadweight ton are taken from UNCTAD. All the variables are converted to per capita form to avoid the biasness which arises due to country size. Each variable is normalized to eliminate scale biasness and then weights are assigned through PCA. This index also passes the diagnostic test of good fit index as the value of Discrepancy (0.0473), RMSR (0.0562), Bollen Relative Fit index, RFI $(0.9013)$ and NFI $(0.9363)$ are in the suggested range.

\subsubsection{Information and communication index (ICT)}

ICT is the composite of internet users, telephone traffic, land line subscription etc. These types of indicators are used in the measurement of globalization under the dimension of technology, personal contact, information flows and social globalization. We have tried to avoid all those variables which are used in its measurement. Hence, we are using ICT imports (percentage of GDP) as a proxy for ICT index. The justification for using ICT imports is that if a country is importing goods related to ICT, then it means it is developing or improving the existing structure of information and communication modes. Data is collected from World Bank data base and Econstat.

\subsection{Financial development index $\left(\mathrm{F}_{\mathrm{it}}\right)$}

Financial development index is collected from IMF database. It is a comprehensive index which uses six indicators of financial institution and financial market to construct financial development index. Depth, access and efficiency of financial institution and financial market are taken. It ranges from zero to one and higher value of the index shows higher financial development. 


\section{Results and Discussion}

Our estimable model given by equation 4.20 involves panel data. In order to choose the right estimation procedure in panel data setting, it is essential to analyze order of integration of the variables in this equation. Several panel units root test are available to determine the stationarity of the series. Following the standard practice, the present study applies tests proposed in Levin, Lin and Chu (2002), Im, Pesaran and Shin (2003) and fisher type tests proposed by Maddala and Wu (1999) and Choi (2001) under the null hypothesis of non-stationary. The alternative hypothesis of Levin et al. (2002) has homogeneous autoregressive coefficient while Im et al. (2003) and

Table 1: Results of Unit Root Test

\begin{tabular}{|c|c|c|c|c|c|}
\hline & $\begin{array}{c}\text { Levin, Lin } \& \\
\text { Chu t* }\end{array}$ & $\begin{array}{c}\text { Im, Pesaran } \\
\text { and Shin } \\
\text { W-stat }\end{array}$ & $\begin{array}{l}\text { ADF - Fisher } \\
\text { Chi-square }\end{array}$ & $\begin{array}{l}\text { PP - Fisher } \\
\text { Chi-square }\end{array}$ & Stationary \\
\hline \multirow{2}{*}{$\begin{array}{l}\text { Human capi- } \\
\operatorname{tal}\left(\mathrm{R}_{\mathrm{it}-1}\right)\end{array}$} & -13.7386 & -6.50160 & 600.280 & 723.200 & \multirow[t]{2}{*}{$\mathrm{I}(0)$} \\
\hline & $(0.000)$ & $(0.000)$ & $(0.000)$ & $(0.000)$ & \\
\hline \multirow{2}{*}{$\begin{array}{l}\text { Efficiency } \\
\text { Index }\left(B_{i t}\right)\end{array}$} & -31.6798 & -14.6845 & 703.085 & 697.777 & \multirow[t]{2}{*}{$\mathrm{I}(0)$} \\
\hline & $(0.000)$ & $(0.000)$ & $(0.000)$ & $(0.000)$ & \\
\hline \multirow{2}{*}{$\begin{array}{c}\text { Capital Stock } \\
\left(\mathrm{K}_{\mathrm{it}}\right)\end{array}$} & -4.388 & -3.066 & 247.141 & 207.949 & \multirow[t]{2}{*}{$\mathrm{I}(1)$} \\
\hline & $(0.000)$ & $(0.001)$ & $(0.001)$ & $(0.108)$ & \\
\hline \multirow{2}{*}{$\begin{array}{l}\text { Labor Force } \\
\quad\left(\mathrm{L}_{\mathrm{it}}\right)\end{array}$} & -9.017 & 1.91332 & 262.333 & 325.730 & \multirow[t]{2}{*}{$\mathrm{I}(0)$} \\
\hline & $(0.000)$ & $(0.972)$ & $(0.000)$ & $(0.000)$ & \\
\hline \multirow{2}{*}{$\begin{array}{c}\text { Transporta- } \\
\text { tion \& Com- } \\
\text { munication } \\
\left(\mathrm{T}_{\mathrm{it}}\right)\end{array}$} & -2.542 & -2.324 & 256.050 & 251.763 & \multirow[t]{2}{*}{$\mathrm{I}(0)$} \\
\hline & 0.005 & $(0.010)$ & $(0.000)$ & $(0.000)$ & \\
\hline \multirow{2}{*}{$\begin{array}{c}\text { Financial } \\
\text { Development } \\
\left(\mathrm{F}_{\mathrm{it}}\right)\end{array}$} & -12.127 & -6.781 & 394.430 & 1036.69 & \multirow[t]{2}{*}{$\mathrm{I}(0)$} \\
\hline & $(0.000)$ & $(0.000)$ & $(0.000)$ & $(0.000)$ & \\
\hline \multirow{2}{*}{$\begin{array}{l}\text { Globalization } \\
\text { Index }\left(G_{i t}\right)\end{array}$} & -20.318 & -12.492 & 513.843 & 1229.38 & \multirow[t]{2}{*}{$\mathrm{I}(0)$} \\
\hline & $(0.000)$ & $(0.000)$ & $(0.000)$ & $(0.000)$ & \\
\hline
\end{tabular}

Note: probability values are given in brackets.

fisher type tests consider heterogeneous autoregressive coefficient. Results of unit root test are presented in Table 1 .

Results of unit root test indicate that all the variables are stationary at level except for the variable of capital which is found to be stationary at first difference. This result 


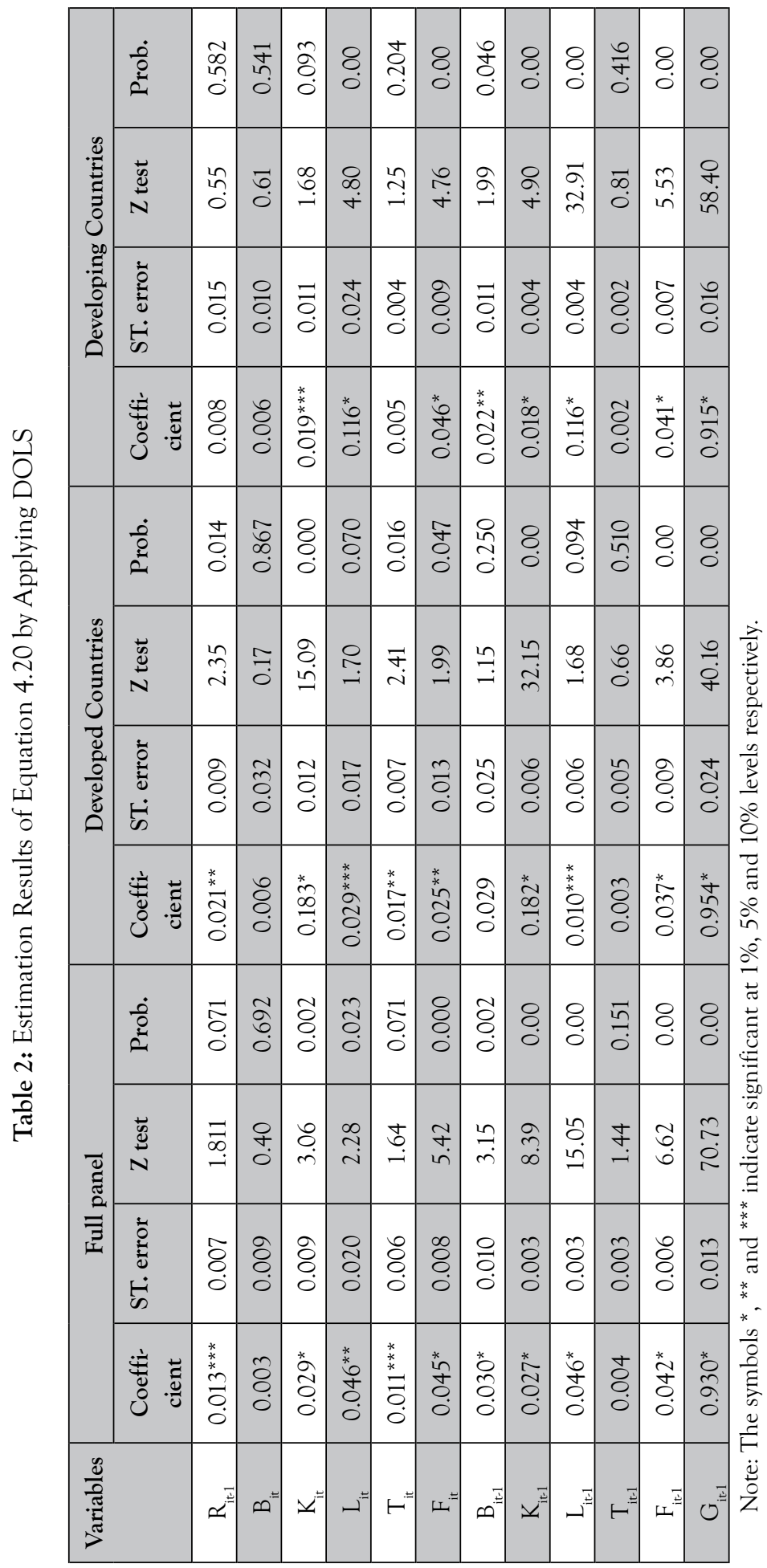


leads to the estimation of equation 4.20 through Dynamic Ordinary Least Square (DOLS) method. It is important to note that this equation is dynamic in nature, containing lagged dependent variable. Therefore, the results of ordinary least square, fixed effect model and random effect model will be biased and inconsistent due to presence of correlation of lag dependent variable with the error term (Holly \& Raissi, 2009).

The results of estimated equation 4.20 are presented in Table 2. Estimation is separately done for developed and developing countries to understand the sources of globalization in these economies. Full panel case presents the combined result of developed and developing countries.

The results show that human capital $\left(\mathrm{R}_{\mathrm{it}-1}\right)$ is positively related to globalization index in case of developed and full panel. It shows that the role of human capital is influential in expediting the process of globalization in developed countries while it appeared to be insignificant in case of developing countries.

Investment in human capital refers to knowledge based economy that is considered to be one of the most important drivers of globalization. Inventions and innovations have created immense transformation in production, transportation and communication. Today decisions regarding consumption, production and other aspects progressively include transnational dimensions. The theory of world-system also highlights the role of knowledge creation for the transformation of the structures.

The role of human resources is critical in complementing investment and policies to boost efficiency and economic activities. It is the investment in human capital that increases the efficiency of labor, which results in the surplus production of good and services. These goods and services are not only enjoyed by the domestic population but their worldwide flow increases economic integration and hence contributes in shaping globalization.

In developing countries, particularly the low income or the poorest ones, the challenges are complex. These countries have lower levels of educational attainment than developed countries and countries with significant numbers of higher formal qualifications works in the areas that under-utilize their skills or end up as unemployed. This is clearly a misallocation and waste of resources in these countries. Therefore, there is a need of new polices and strategies to establish link between investment in skill development and productivity to drive the process of globalization smoothly across globe which otherwise surpass these low income countries.

Efficiency $\left(\mathrm{B}_{\mathrm{it}}\right)$, labor $\left(\mathrm{L}_{\mathrm{it}}\right)$ and capital $\left(\mathrm{K}_{\mathrm{it}}\right)$ are the components of output. In this analysis labor and capital are positively effecting globalization while efficiency is insignificant in developed, developing and full panel cases. However, the impact 
of lagged values of efficiency $\left(\mathrm{B}_{\mathrm{it}-1}\right)$, labor $\left(\mathrm{L}_{\mathrm{it}-1}\right)$ and capital $\left(\mathrm{K}_{\mathrm{it}-1}\right)$ are significant on globalization except for the value of $\left(\mathrm{B}_{\mathrm{it}-1}\right)$ in developed countries. It highlights that the current form of globalization is determined by previous stock of capital, labor and the performance of the economy in terms of economic diversification, labor reallocation, international competitiveness, macroeconomic instability and governance.

The role of capital and labor can be explained by observing the returns of these factors. The objective of producer is to maximize profits that can be realized by employing cheap factor of production. Therefore, producer sets its business in that region where there is cheap availability of labor. It is termed as outsourcing that is the most obvious and beneficial cost saving approach. Another explanation in context of factor returns can be found from the traditional philosophy of self-interest. Labor migrates to the area of better economic opportunities or where it can get better returns of his labor work in the form of wages. Likewise, capital flow to the areas where it gets higher returns in terms of interest. It clearly indicates that the motive of self-interest moves labor and capital from one country to another, thereby contributing in the process of global integration. These instances illustrate the way factor of production contributes to globalization.

In context of the globalization theories, the theory of global capitalism states the expansionary nature of capitalism, which requires cheap labor, raw material and market for its survival. Hence, transnational capital derives the process of globalization. Similarly, according to the theory of transnational and transnationalism, individuals/ labor creates transnational link which allow them to live in transnational space. It shows that the movement of individuals/labors is not bounded to particular location. Therefore, it allows globalization to take place.

In this study, the coefficient of transportation and communication index $\left(T_{i t}\right)$ is found to be significant in full panel and developed countries whereas it is insignificant in developing countries.

Technological improvement in telecommunication and transportation is perceived as a major facilitator of globalization. The development of digital technology and internet has made significant changes in information and telecommunication sector. The World Wide Web (www) has enabled individuals to access information across globe. Additionally, global media networks with its branches in various countries bring news and information to individuals all over the globe.

Improvement in transportation has not only changed the way of businesses but also tourism. Massive container ships and super tankers have taken the scale of trade to higher level. Modern transport is able to carry large quantity of goods including 
liquid such as oil. This has increased the international trade between countries.

The revolution in the industries of transportation, communication and information has added new meaning to the process of globalization. It has significantly improved the degree of connectivity among various regions of the globe and made it a flat world. The theories of world-system, global capitalism, network society and others also explain the role of technological improvement as an important factor for the creation of global world.

Surprisingly, in developing countries the important coefficient of transportation and communication turns out to be insignificant. It can be due to uneven access of technology around the globe, especially in poor countries. The access and use of broadband and internet is much lower in poor countries. Furthermore, lack of supporting ICT applications and human capacity does not complement the required sustenance to globalization. Weak infrastructure of the low income countries restricts the process of globalization via transportation and communication. Lower degree of globalization is an evidence of poor air, sea and land ways management of poorer countries. In our sample countries like Albania, Algeria, Armenia, Bangladesh and etc show lower value of transportation and communication index, thereby unable to significantly affect the process of globalization through this channel. However, the positive relationship is evident from this study.

The study reports that financial development $\left(\mathrm{F}_{\mathrm{i}}\right)$ and the lagged value of financial index $\left(\mathrm{F}_{\mathrm{it}-1}\right)$ is significant and directly related to globalization in all three cases. It means the financial institutions are stronger enough to derive the process the globalization in developed as well as in developing countries. Capital account liberalization and deregulation are the financial drivers of globalization. It is observed that international transactions in liquid assets have been increased around the world over the last few decades. Financial institutions and corporations including banks have expanded their activities worldwide. The market products and instruments of financial sector facilitate borrower and lender all over the world to economize possible risks. Hence, the higher degree of integration among countries seems to be driven by financial sector.

Technological progress and financial innovation played an important role in determining the current shape of globalization. Cross boarder financial flow has become easier and secure due to efficient and reliable global networks particularly electronic banking. Strong financial institutions make it easier to move finances globally in order to exploit its maximum gains. Hence the role of financial sectors is significant in increasing the economic integration through financial globalization.

The contribution of financial index to globalization is high in developing countries 


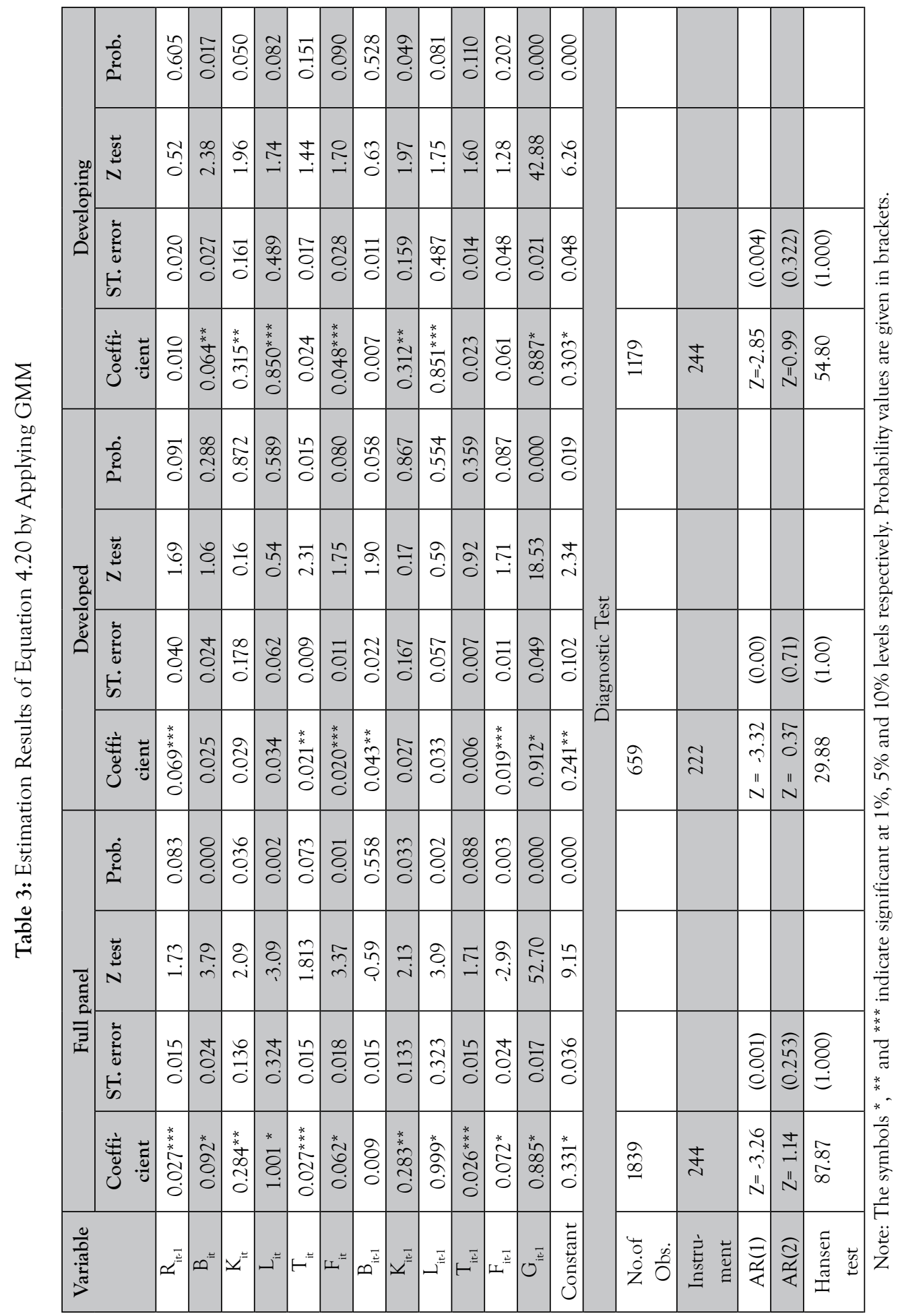


i.e. 0.04 than in developed countries. The reason for this high value can be the flow of capital from advanced economies to developing countries in search of cheap labor. Therefore this global movement of capital increases the financial connectivity which later reflects in economic integration. This result indicates that the financial sectors significantly drive the process of globalization in developing and emerging economies.

Lagged value of globalization $\left(\mathrm{G}_{\mathrm{it}-1}\right)$ appeared to be the most strongest to effect current globalization. The dynamic mechanism of globalization creates pressure for the harmonization of economic, political, cultural, social and financial systems across boarder, which, in turn lead to more globalization. It simply referred as globalization begets globalization.

\section{Results of Generalized Methods of Moments (GMM) for Robustness}

For robust check Equation 4.20 is also estimated by applying the technique of system generalized methods of moments (GMM). The results are presented in Table 3.

The results of full panel case and developing countries are almost similar to the one which have been derived from DOLS expect for the variable of efficiency. In this analysis the coefficient of efficiency is significant in driving globalization. Efficiency index represents the trade, macroeconomic and political efficiency of a country. It obviously means that the efficient structure regulates international movement of goods and services hence facilitate the process of integration among regions. It is noted that results of GMM are stronger in determining globalization as the magnitude of coefficients are greater.

In case of developed countries the index of human capital, transport and communication and financial setup majorly drives the process of globalization.

The reliability and validity of the instruments are shown by the serial correlation tests, mentioned as AR(1), AR(2) and the Hansen test in Table 3. Results indicate the existence of serial correlation at first order AR(1), but not at second order AR(2). However, the more relevant is AR(2) test of serial correlation ${ }^{5}$. P-value of the Hansen test indicates exogeneity of the instruments which are used to estimate dynamic system GMM since we are unable to reject the null hypothesis in all three cases.

\section{Conclusion and Policy Recommendations}

There are several economic, political, social and technological factors that have contributed to globalization in recent decades. It includes lower trade and capital restrictions that have increased the flow of international trade and capital across

5 The differenced in error term is likely to be serially correlated at first order even if the original error is not. 
globe. Market and cost drivers have also contributed in affecting the degree of integration among countries. The costs of transportation and communication have fallen dramatically due to technological improvement that promotes the culture of borderless economies.

The current study has developed a formal framework, which highlights the sources of globalization. Overall it is concluded that the results of DOLS shows human capital, capital, labor, transportation and communication and financial index as the important drivers of globalization in the combined panel and developed countries.

The panel of developing countries highlights capital, labor and financial index to determine the process of globalization. The role of human capital and transportation and communication is not significant; therefore, it is recommended that there is a need of investment on human skills and infrastructure in developing countries to keep pace with other countries.

Results of GMM estimation in full panel and developing countries are similar. However, in this case efficiency index is appeared to be significant. In the panel of developed countries human capital, transportation and communication and financial index are significant. GMM estimation successfully passes all the diagnostic tests.

Integration of economies has developed a new culture of interdependence. Therefore, it is required to integrate national economies to the rest of the world in order to take advantage of modern technologies and innovation. Application of these technologies is a challenge for most of the low income countries due to lack of investment on human capital. The role of human capital is not significant in determining the process of globalization in developing countries. It is therefore recommended that there is a need of investment on human skills in developing countries to keep pace with other countries. Furthermore, development of infrastructure is required to accelerate trade flow among countries.

\section{References}

Aghion, P., \& Howitt, P. (1990). A model of growth through creative destruction. National Bureau of Economic Research.

Ali, A., \& Rehman, H. U. (2015). Macroeconomic instability and its impact on gross domestic product: An empirical analysis of Pakistan. Pakistan Economic and Social Review, 53(2), 285-316.

Arrow, K. (1962). Economic welfare and the allocation of resources for invention. In The rate and direction of inventive activity: Economic and social factors. (pp. 609-626). Princeton University Press.

Bang, K. E., \& Markeset, T. (2011). Impact of globalization on model of competition and companies' compet- 
itive situation. Paper presented at the IFIP International Conference on Advances in Production Management Systems.

Bauernfeind, M. (2006). Drivers of globalization: Integration of theories and models. GRIN Publishing.

Castells, M. (1996). The information age: Economy, society, and culture: The rise of the network society. Wiley-Blackwell.

Choi, I. (2001). Unit root tests for panel data. Journal of International Money and Finance, 20(2), 249-272.

Dijk, J. (1991). De netwerkmaatschappij. Sociale aspecten van nieuwe media, Samsom, Alphen aan den Rijn.

Fofack, H. (2009). Determinants of globalization and growth prospects for Sub-Saharan African countries. World Bank Policy Research Working Paper Series.

Garrett, G. (2000). The causes of globalization. Comparative political studies, 33(6-7), 941-991.

Giddens, A. (1990). 1990: The consequences of modernity. Cambridge: Polity Press.

Grossman, G. M., \& Helpman, E. (1991a). Quality ladders in the theory of growth. The Review of Economic Studies, 58(1), 43-61.

Grossman, G. M., \& Helpman, E. (1991b). Trade, knowledge spillovers, and growth. European Economic Review, 35(2-3), 517-526.

Grossman, G., \& Helpman, E. (1991c). Innovation and growth in the global economy. The MIT Press.

Harberger, A. C. (1978). On the use of distributional weights in social cost-benefit analysis. Journal of Political Economy, 86(2, Part 2), S87-S120.

Harris, R. G. (1993). Globalization, trade, and income. The Canadian Journal of Economics/Revue canadienne d'Economique, 26(4), 755-776.

Harvey, D. (1990). The Condition of Post-Modernity. London: Blackwell.

Holly, S., \& Raissi, M. (2009). The macroeconomic effects of European financial development: A heterogenous panel analysis (No. D. 1.4). FINESS Working Paper.

Im, K. S., Pesaran, M. H., \& Shin, Y. (2003). Testing for unit roots in heterogeneous panels. Journal of Econometrics, 115(1), 53-74.

Jones, C. I. (1995). R \& D-based models of economic growth. Journal of Political Economy, 103(4), 759-784.

Kneller, R., \& Stevens, P. A. (2002). Absorptive capacity and frontier technology. Evidence from OECD Manufacturing Industries. Retrieved from https://s3.amazonaws.com/academia.edu.documents/45298648/ Frontier_Technology_and_Absorptive_Capac20160502-3998-f97xrd.pdf?AWSAccessKeyId=AKIAIWOWYYGZ2Y53UL3A\& Expires=1526557096\& Signature=7ZBonDKw8hOKGP299HjSPCsFQeI\%3D\& response-content-disposition=inline\%3B\%20filename\%3DFrontier_technology_and_absorptive_capac.pdf 
Krugman, P. (1980). Scale economies, product differentiation, and the pattern of trade. The American Economic Review, 70(5), 950-959.

Lane, P. R., \& Milesi-Ferretti, G. M. (2008). The drivers of financial globalization. The American Economic Review, 98(2), 327-332.

Levin, A., Lin, C. F., \& Chu, C. S. J. (2002). Unit root tests in panel data: Asymptotic and finite-sample properties. Journal of Econometrics, 108(1), 1-24.

Looney, R. E. (1985). Economic policymaking in Mexico: Factors underlying the 1982 crisis. Duke University Press.

Maddala, G. S., \& Wu, S. (1999). A comparative study of unit root tests with panel data and a new simple test. Oxford Bulletin of Economics and Statistics, 61(S1), 631-652.

Maddison, A. (2001). Monitoring the World Economy: A Millennial Perspective. Paris: OECD.

Martin, J. (1978). The wired society. (pp. 300). Englewood Cliffs, NJ: Prentice-Hall.

Masson, M. P. R. (2001). Globalization facts and figures (No. 1-4). International Monetary Fund.

Mishkin, F. S. (2006). The next great globalization: How disadvantaged nations can harness their financial systems to get rich. Princeton University Press.

Mussa, M. (2000). Factors driving global economic integration. Global economic integration: Opportunities and challenges, 9-55.

Obadan, M. (2008). Economic globalization, markets and national development: How sensibly do the poor countries (Nigeria included) stand? Retrieved from https://core.ac.uk/download/pdf/14520679.pdf

Reynolds, C. (1971) The Mexican Economy. New Haven, CT.: Yale University Press.

Ritzer, G. (2011). Globalization: The essentials. John Wiley \& Sons.

Robinson, W. I. (2004). A theory of global capitalism: Production, class, and state in a transnational world. JHU Press.

Romer, P. M. (1986). Increasing returns and long-run growth. Journal of political economy, 94(5), 1002-1037.

Romer, P. (1990). Endogenous technological change. Journal of Political Economy, 98(5), 71-102.

Sassen, S. (1991). The Global City: New York. London, Tokyo, 41.

Stiglitz, J., \& Greenwald, B. (2003). Towards a new paradigm in monetary economics. Cambridge University Press.

Wallerstein, I. (1974). The rise and future demise of the world capitalist system: Concepts for comparative analysis. Comparative Studies in Society and History, 16(4), 387-415.

World Bank (2002). Globalization, Growth and Poverty. Policy research reports. 
Appendix-I List of Developing Counties (By IMF Criterion)

\begin{tabular}{|c|c|c|}
\hline 1.Albania & 21.Hungary & 41.Russian \\
\hline 2.Algeria & 22.India & 42.Senegal \\
\hline 3.Argentina & 23.Indonesia & 43.South Africa \\
\hline 4.Armenia & 24.Iran & 44.Sri Lanka \\
\hline 5.Bangladesh & 25.Jordan & 45. Paraguay \\
\hline 6.Belize & 26.Kazakhstan & 46. ElSalvador \\
\hline 7.Benin & 27.Kenya & 47. Egypt \\
\hline 8.Bolivia & 28.Madagascar & 48. Guatemala \\
\hline 9.Brazil & 29.Malaysia & 49. Tanzania \\
\hline 10.Brunei & 30.Mauritius & 50. Thailand \\
\hline 11.Bulgaria & 31.Mexico & 51. Togo \\
\hline 12.Burkina & 32.Mongolia & 52. Trinidad\& Tobago \\
\hline 13.Cambodia & 33.Morocco & 53. Tunisia \\
\hline 14.Cameroon & 34.Namibia & 54. Turkey \\
\hline 15.China & 35.Nigeria & 55. Uganda \\
\hline 16.Colombia & 36.Pakistan & 56. Ukraine \\
\hline 17.Sudan & 37.Peru & 57. Uruguay \\
\hline 18.Croatia & 38.Philippines & 58. Venezuela \\
\hline 19.Gabon & 39.Poland & 59. Vietnam \\
\hline 20.Ghana & 40.Romania & \\
\hline \multicolumn{3}{|c|}{ List of Developed Countries } \\
\hline 1.Australia & 13.Ireland & 25.Slovak \\
\hline 2.Austria & 14.Israel & 26.Slovenia \\
\hline 3.Belgium & 15.Italy & 27.Spain \\
\hline 4.Canada & 16.Japan & 28.Sweden \\
\hline 5.Chile & 17.Korea & 29.Switzerland \\
\hline 6.Czech Rep. & 18.Latvia & 30. Malta \\
\hline 7.Denmark & 19.Lithuania & 31.Iceland \\
\hline 8.Estonia & 20.Luxembourg & 32. UK \\
\hline 9.Finland & 21.Netherlands & 33.USA \\
\hline 10.France & 22.NewZealand & \\
\hline 11.Germany & 23.Norway & \\
\hline 12.Greece & 24.Portugal & \\
\hline
\end{tabular}


